\title{
A Conditional Logistic Regression Model for Analyzing Unemployment Rates in West Java*
}

\author{
Model Regresi Logistik Bersyarat untuk Analisis Tingkat \\ Pengangguran di Provinsi Jawa Barat
}

Dwi Jayanti ${ }^{1}$, Septian P Palupi ${ }^{2}$, and Khairil Anwar Notodiputro ${ }^{3 \ddagger}$

\author{
${ }^{1}$ Badan Pusat Statistik, Indonesia \\ 2,3 Department of Statistics, IPB University, Indonesia \\ ¥corresponding author : khairil@apps.ipb.ac.id
}

Copyright ( 2021 Dwi Jayanti, Septian P Palupi, and Khairil Anwar Notodiputro. This is an openaccess article distributed under the Creative Commons Attribution License, which permits unrestricted use, distribution, and reproduction in any medium, provided the original work is properly cited.

\begin{abstract}
Unemployment is a critical problem faced by developing countries. It is a complex problem which creates other social and economic problems such as poverty, economic gaps, and crimes. This paper discusses the determinant factors of unemployment rates based on empirical data using the conditional logistic regression model. The model was used to analyze matched pair data using gender, age and residence as matching factors. The result showed that household status, marriage status, as well as levels of education were the determinant factors of a person being unemployed in West Java. It is also shown that the conditional logistic regression outperformed the standard logistic regression for analyzing the cause of unemployment.
\end{abstract}

Keywords: case-control, confounding, covariate, individual matching, odds ratio.

\footnotetext{
* Received: Jan 2021; Reviewed: Mar 2021; Published: Mar 2021
} 


\section{Pendahuluan}

Pengangguran merupakan masalah krusial bagi suatu negara terutama negara berkembang. Menurut (Sukirno \& Sukirno, 2010) pengangguran merupakan kondisi dimana seseorang yang tergolong dalam angkatan kerja dan aktif mencari pekerjaan namun belum memperoleh pekerjaan. Pengangguran ini terjadi karena adanya ketidakseimbangan antara permintaan dan penawaran tenaga kerja. Penambahan lapangan kerja yang tersedia tidak cukup luas untuk menampung tingginya pertambahan angkatan kerja.

Menurut data BPS, pada Agustus 2018 tingkat pengangguran di Indonesia sebesar 5,34 persen. Walaupun jumlah pengangguran cenderung menurun sejak tahun 2015, namun Indonesia masih merupakan negara dengan tingkat pengangguran tertinggi di kawasan ASEAN (Kevin, 2019). Untuk level provinsi tingkat pengangguran sangat beragam, sebagai gambaran pada Februari 2019 pengangguran tertinggi terjadi di Jawa Barat, yaitu sebesar 7,73 persen.

Dalam studi observasional hubungan sebab akibat antara peubah penjelas dengan peubah respon akan berbias jika mengabaikan keberadaan confounder. Peubah confounding mendistorsi hubungan antara peubah penjelas dan peubah respon sehingga hubungan sebenarnya tidak tampak. Adanya confounder ini dapat menyebabkan prediksi yang tidak akurat (overestimate atau underestimate) dan berdampak pada sulitnya membangun hubungan sebab akibat sehingga perlu dilakukan koreksi efek confounding. Untuk mengatasi bias akibat adanya peubah confounding perlu dilakukan pemadanan (matching) menggunakan kovariat yang sesuai (Pearce, 2016). Analisis dengan metode pemadanan, misalnya conditional logistic regression, menghasilkan estimasi yang kekar dan tidak berbias (Kuo et al., 2018). Salah satu penelitian untuk mempelajari berbagai faktor yang mempengaruhi status pengangguran di perdesaan di Jawa Tengah telah dilakukan oleh Hartina (2009). Dalam penelitian tersebut digunakan model regresi logistik dengan peubah penjelas adalah umur, jenis kelamin, status perkawinan, status dalam rumah tangga, tingkat pendidikan, dan pekerjaan. Peubah responnya bersifat biner (pengangguran atau bukan pengangguran). Namun demikian dalam analisis ini adanya peubah confounding dan kovariat tidak dipertimbangkan oleh peneliti.

Berbeda dengan penelitian yang lain, dalam makalah ini dibahas model yang mempertimbangkan adanya peubah confounding menggunakan model regresi logistik bersyarat. Ada dua isu yang dibahas dalam makalah ini. Pertama, isu perbandingan antara model regresi logistik bersyarat untuk data berpadanan dan regresi logistik baku untuk data tanpa pemadanan untuk memahami efek confounding dan kovariat. Kedua, isu tentang berbagai faktor yang mempengaruhi status pengangguran di Provinsi Jawa Barat berdasarkan model regresi logistik bersyarat melalui pemadanan pengamatan. Tingkat pendidikan, status pernikahan, dan status hubungan dengan kepala rumah tangga dijadikan peubah penjelas dalam kajian ini. Selanjutnya, peubah confounding yang digunakan adalah klasifikasi wilayah dan jenis kelamin, sedangkan yang menjadi peubah kovariat adalah usia. 


\section{Metodologi}

\subsection{Bahan dan Data}

Data yang digunakan dalam analisis ini adalah data hasil Survei Angkatan Kerja Nasional (SAKERNAS) Agustus 2018 yang dilakukan oleh Badan Pusat Statistik (BPS). SAKERNAS merupakan survei untuk mengumpulkan data ketenagakerjaan melalui kuesioner terhadap rumah tangga contoh ([BPS], 2018). Dalam kajian ini digunakan data untuk Provinsi Jawa Barat mengingat pengangguran di provinsi ini merupakan yang tertinggi di Indonesia. Deskripsi dari berbagai peubah yang digunakan dalam kajian ini disajikan pada Tabel 1.

Tabel 1: Peubah respon, penjelas, confounding dan kovariat

\begin{tabular}{|c|c|c|c|c|c|}
\hline No & Nama Peubah & Simbol & Jenis peubah & $\begin{array}{c}\text { Skala } \\
\text { peubah }\end{array}$ & Deskripsi \\
\hline 1 & $\begin{array}{l}\text { Status } \\
\text { Pengangguran }\end{array}$ & $\mathrm{Y}$ & $\begin{array}{l}\text { Peubah } \\
\text { respon }\end{array}$ & Nominal & $\begin{array}{l}\text { 1. Bekerja } \\
\text { 2. Menganggur (case) }\end{array}$ \\
\hline 2 & $\begin{array}{l}\text { Status dalam } \\
\text { Keluarga }\end{array}$ & $\mathrm{X} 1$ & $\begin{array}{l}\text { Peubah } \\
\text { Penjelas }\end{array}$ & Nominal & $\begin{array}{l}\text { 1. Kepala rumah tangga } \\
\text { 2. Bukan kepala rumah } \\
\text { tangga }\end{array}$ \\
\hline 3 & $\begin{array}{l}\text { Status } \\
\text { Pernikahan }\end{array}$ & $\mathrm{X} 2$ & $\begin{array}{l}\text { Peubah } \\
\text { Penjelas }\end{array}$ & Nominal & $\begin{array}{l}\text { 1. Belum kawin } \\
\text { 2. Kawin } \\
\text { 3. Cerai }\end{array}$ \\
\hline 4 & $\begin{array}{l}\text { Tingkat } \\
\text { Pendidikan }\end{array}$ & X3 & $\begin{array}{l}\text { Peubah } \\
\text { Penjelas }\end{array}$ & Nominal & $\begin{array}{l}\text { 1. SD dan dibawahnya } \\
\text { 2. SMP dan sederajatnya } \\
\text { 3. SMA dan sederajatnya } \\
\text { 4. Diploma dan diatasnya }\end{array}$ \\
\hline 5 & $\begin{array}{l}\text { Klasifikasi } \\
\text { wilayah }\end{array}$ & $\mathrm{C} 1$ & $\begin{array}{l}\text { Peubah } \\
\text { Confounding }\end{array}$ & Nominal & $\begin{array}{l}\text { 1. Perkotaan } \\
\text { 2. Perdesaan }\end{array}$ \\
\hline 6 & Jenis Kelamin & $\mathrm{C} 2$ & $\begin{array}{l}\text { Peubah } \\
\text { Confounding }\end{array}$ & Nominal & $\begin{array}{l}\text { 1. Laki-laki } \\
\text { 2. Perempuan }\end{array}$ \\
\hline 7 & Usia & C3 & $\begin{array}{l}\text { Peubah } \\
\text { Kovariat }\end{array}$ & Rasio & - \\
\hline
\end{tabular}

Untuk memastikan apakah seseorang termasuk menganggur atau bekerja maka perlu didefinisikan terlebih dahulu apa dimaksud dengan bekerja dan menganggur. Bekerja merupakan kondisi dimana orang yang termasuk angkatan kerja dan bekerja minimal 1 jam (tanpa putus) dalam seminggu atau bekerja namun dalam kondisi tidak sedang bekerja minimal 1 jam (tanpa putus) dalam seminggu ([BPS], 2017). Sedangkan menganggur adalah kondisi dimana orang yang termasuk angkatan kerja namun tidak sedang bekerja minimal 1 jam (tanpa putus) dalam seminggu.

\subsection{Metode Penelitian}

Model regresi logistik adalah model regresi dengan peubah respon berupa peubah kategorik (biner, nominal, atau ordinal) dan peubah penjelas numerik maupun 
kategorik (Agresti, 2002). Peubah respon status bekerja $(Y)$ dengan dua kemungkinan yakni $Y=1$ jika menganggur dan $Y=0$ jika bekerja. Model regresi logistik bersyarat memanfaatkan adanya strata atau pemadanan berdasarkan kovariat atau confounding. Pada pemadanan (1:1) jumlah anggota masing-masing strata adalah dua, dan banyaknya strata adalah banyaknya pasangan. Model regresi logistik bersyarat dalam analisis ini diekspresikan sebagai berikut:

$$
P\left(Y_{i l}=1 \mid X_{i l}\right)=\frac{\exp \left(\beta_{0 i}+\beta_{1} D_{1 i l}+\beta_{2} D_{21 i l}+\beta_{3} D_{22 i l}+\beta_{4} D_{31 i l}+\beta_{5} D_{32 i l}+\beta_{6} D_{33 i l}\right)}{1+\exp \left(\beta_{0 i}+\beta_{1} D_{1 i l}+\beta_{2} D_{21 i l}+\beta_{3} D_{22 i l}+\beta_{4} D_{31 i l}+\beta_{5} D_{32 i l}+\beta_{6} D_{33 i l}\right)}
$$

Dengan $P\left(Y_{i l}=1 \mid X_{i l}\right)$ adalah peluang seseorang menganggur pada strata ke- $i$ pengamatan ke- $l$ dan $i$ adalah indeks strata berdasarkan confounding dan kovariat.

$$
\begin{aligned}
& D_{1}=\left\{\begin{array}{l}
1, \text { jika kepala rumah tangga } \\
0, \text { jika bukan kepala rumah tangga }
\end{array}\right. \\
& D_{21}=\left\{\begin{array}{l}
1, \text { jika status perkawinan adalah kawin } \\
0, \text { jika lainnya }
\end{array}\right. \\
& D_{22}=\left\{\begin{array}{l}
1, \text { jika status perkawinannya adalah cerai } \\
0, \text { jika lainnya }
\end{array}\right. \\
& D_{31}=\left\{\begin{array}{l}
1, \text { jika tingkat pendidikan SMP dan setaranya } \\
0, \text { jika lainnya }
\end{array}\right. \\
& D_{32}=\left\{\begin{array}{l}
1, \text { jika tingkat pendidikannya SMA dan setaranya } \\
0, \text { jika lainnya }
\end{array}\right. \\
& D_{33}=\left\{\begin{array}{l}
1, \text { jika tingkat pendidikan Diploma dan setaranya } \\
0, \text { jika lainnya }
\end{array}\right. \\
& \beta_{j} \text { adalah koefisien regresi dengan } j=1,2, \ldots, 6
\end{aligned}
$$

\subsection{Pendugaan Parameter}

Parameter model regresi logistik diduga menggunakan metode kemungkinan maksimum (Maximum Likelihood) dengan memaksimumkan fungsi kemungkinan sebagai berikut:

$$
L(\boldsymbol{\beta})=\prod_{i=1}^{n} \prod_{l=1}^{m} \pi\left(x_{i l}\right)^{y_{i l}}\left(1-\pi\left(x_{i l}\right)\right)^{1-y_{i l}}
$$

dengan:

$y_{i l}=$ pengamatan respon $\mathrm{ke}-l$ strata ke-i dengan $i=1,2, \ldots, \mathrm{n}$ dan $l=1, \ldots, \mathrm{m}$

$\mathrm{n} \quad$ = banyaknya pasangan

$\mathrm{m}=$ banyaknya anggota dalam strata (dalam pemadanan 1:1) nilai $m=2$

$\pi\left(x_{i l}\right)=$ peluang kejadian ke-l pada strata ke- $i$

\subsection{Pengujian Parameter}

Pengujian parsial dilakukan dengan uji Wald. Hipotesis yang diuji adalah: $H_{0}: \beta_{j}=0$ (peubah penjelas $X_{j}$ tidak berpengaruh terhadap peubah respon) $H_{0}: \beta_{j} \neq 0$ (peubah penjelas $X_{j}$ berpengaruh terhadap peubah respon) untuk $j=1,2, \ldots, 6$ Statistik uji Wald adalah sebagai berikut:

$$
W=\frac{\widehat{\beta_{J}}}{S E\left(\widehat{\beta}_{J}\right)}
$$


Statistik uji W bersebaran normal baku dengan nilai kritis sebesar $Z_{\alpha / 2}$ untuk uji dua arah. Hipotesis akan ditolak jika $W>Z_{\alpha / 2}$ atau nilai-p< $\alpha$ (Hosmer \& Lemeshow, 2000).

\subsection{Pengujian Parameter}

Tahapan analisis adalah sebagai berikut:

1. Melakukan analisis deskriptif dengan menggunakan proporsi data pengangguran berdasarkan peubah bebas dan confounding-nya.

2. Melakukan pemodelan regresi logistik dengan menggunakan data tanpa pemadanan dengan peubah bebas X1, X2, dan X3 (Unconditional Logistic Regression).

3. Melakukan pengujian dan interpretasi hasil pemodelan.

4. Melakukan proses pemadanan data berdasarkan peubah klasifikasi wilayah (C1), jenis kelamin (C2), dan usia (C3). Pemadanan dilakukan pada level individu menggunakan nilai sebenarnya dari suatu peubah (bukan nilai yang dikategorikan). Peubah umur yang digunakan sebagai pemadan adalah umur dalam tahun (bukan dalam bentuk kategori). Proses pemadanan data dilakukan dengan proses sebagai berikut:

a. Memilih kasus dan pasangan secara acak.

b. Memilih kontrol dan pasangan secara acak

5. Melakukan pemodelan dengan metode conditional logistic regression dengan peubah bebas X1, X2, X3 menggunakan data yang sudah dipadankan

6. Melakukan pengujian dan interpretasi hasil pemodelan

7. Membandingkan dan membuat kesimpulan dari 2 pemodelan.

Pengolahan data regresi logistik bersyarat dilakukan dengan menggunakan fungsi clogit() pada package survival di program R. Sedangkan pengolahan regresi logistik tidak bersyarat menggunakan fungsi $g \operatorname{lm}()$.

\section{Hasil dan Pembahasan}

\subsection{Profil Responden yang Menganggur}

Persentase orang yang menganggur di Provinsi Jawa Barat berdasarkan berdasarkan status dalam keluarga ditampilkan pada Gambar 1. Persentase pengangguran didominasi oleh orang dengan status sebagai bukan kepala rumah tangga sebesar 60 persen. Hal ini terkait dengan tanggung jawab dalam keluarga, orang dengan posisi sebagai kepala ruma tangga akan cenderung untuk bekerja. Persentase pengangguran berdasarkan status pernikahannya dapat dilihat di Gambar 2 . Pengangguran di Jawa Barat mayoritas bercerai yakni sebesar 43 persen. 


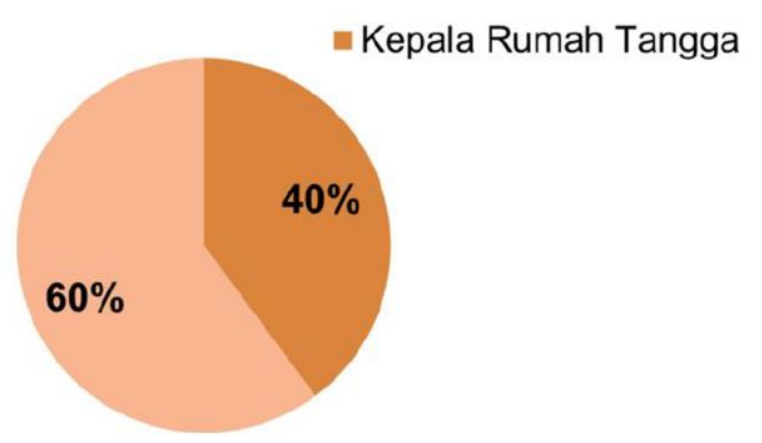

Bukan Kepala Rumah Tangga

Gambar 1: Persentase pengangguran di Provinsi Jawa

Barat berdasarkan status dalam keluarga

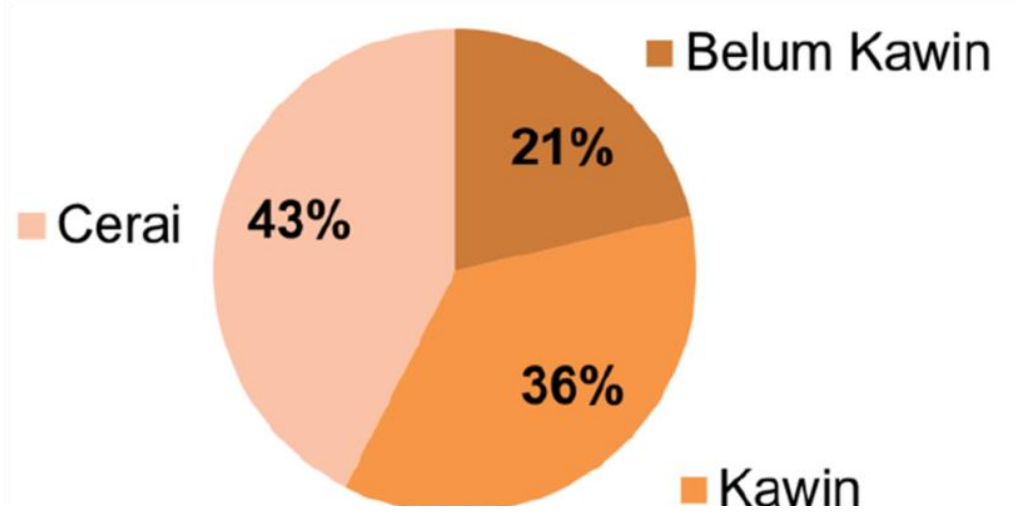

Gambar 2: Persentase pengangguran di Provinsi Jawa Barat berdasarkan status pernikahan

Persentase pengangguran berdasarkan tingkat pendidikan di Provinsi Jawa Barat dapat dilihat pada Gambar 3. Orang dengan status menganggur didominasi oleh orang dengan tingkat pendidikan SD dan dibawahnya (tidak lulus SD/tidak sekolah) yakni sebanyak 75 persen. Hal ini sesuai dengan teori human capital bahwa orang dengan pendidikan yang tinggi akan mendapat kesempatan kerja yang lebih banyak (Mankiw, 2006). Sedangkan orang dengan pendidikan yang rendah akan lebih sedikit peluang untuk bekerja terutama di sektor formal.

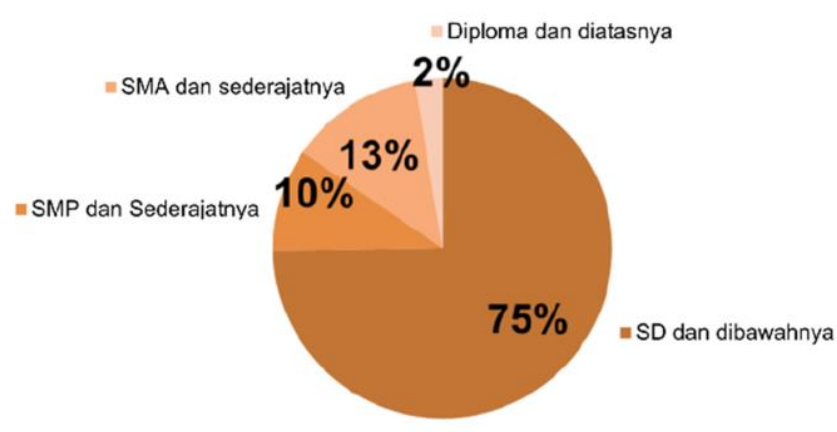

Gambar 3: Persentase pengangguran di Provinsi Jawa Barat berdasarkan tingkat pendidikan 
Persentase pengangguran berdasarkan jenis kelamin dapat dilihat di Gambar 4. Pengangguran di Jawa Barat sebagian besar tinggal di perdesaan, yakni sebanyak 56 persen. Lapangan pekerjaan di perdesaan didominasi oleh pekerjaan di sektor pertanian. Sehingga besarnya pengangguran di perdesaan biasanya terkait pada fase pekerjaan di sektor pertanian. Jika pada masa panen atau tanam maka jumlah pengangguran akan berkurang. Namun sebaliknya, jika sedang di luar masa itu maka pengangguran akan meningkat. Persentase pengangguran berdasarkan jenis kelamin ditampilkan di Gambar 5. Sebagian besar pengangguran di Provinsi Jawa Barat berjenis kelamin laki-laki yakni sebesar 53 persen.

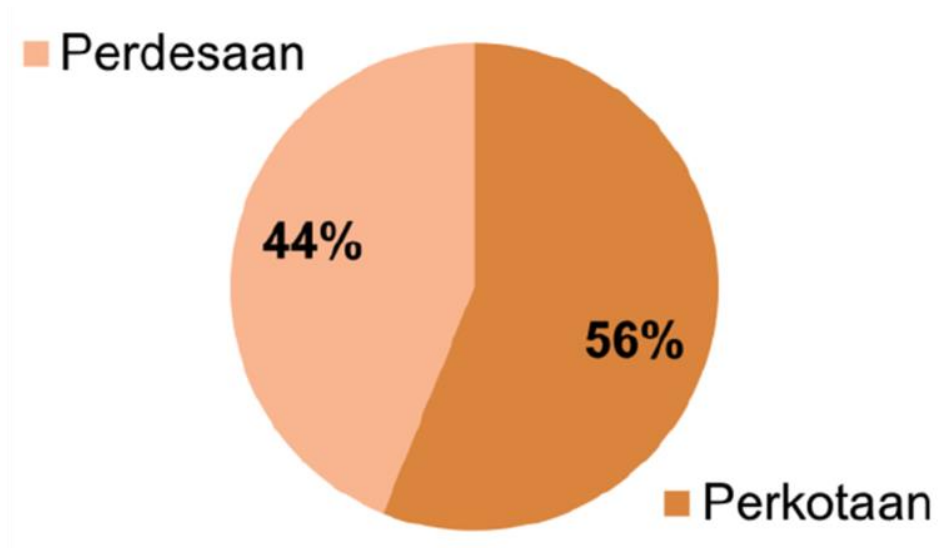

Gambar 4: Persentase pengangguran di Provinsi Jawa Barat berdasarkan klasifikasi wilayah

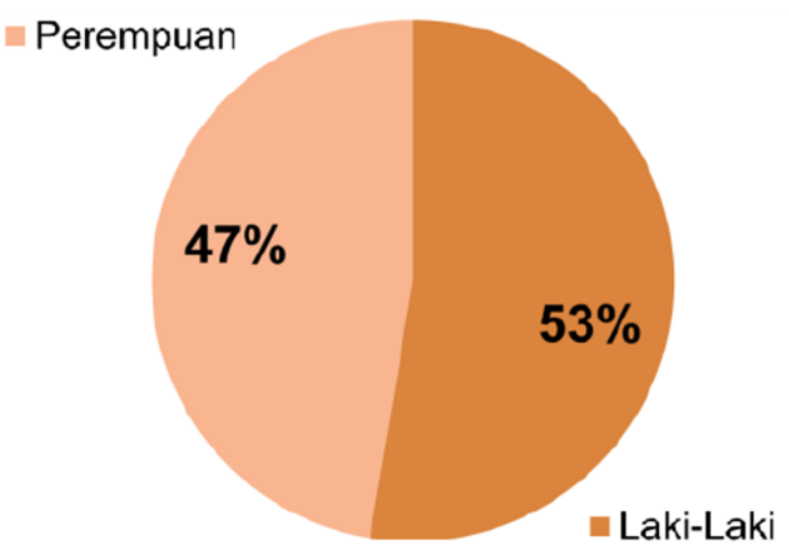

Gambar 5: Persentase pengangguran di Provinsi Jawa Barat berdasarkan jenis kelamin

\subsection{Regresi Logistik tanpa Pemadanan (Unconditional Logistic Regression) dan Regresi Logistik dengan Pemadanan (Conditional Logistic Regression)}

Pemadanan data berdasarkan klasifikasi wilayah, jenis kelamin, dan usia menghasilkan sebanyak 415 pasangan. Sehingga untuk pemodelan regresi logistik dengan pemadanan (conditional logistic regression) digunakan sebanyak 830 data. 
Pemadanan ini bertujuan untuk menyeragamkan kondisi responden berdasarkan klasifikasi wilayah, jenis kelamin, dan usia baik responden dengan status menganggur dan status bekerja. Dengan adanya proses pemadanan ini diharapkan akan mampu mengeliminasi bias pada hubungan antara peubah bebas dengan respon.

Tabel 2 menunjukkan bahwa untuk analisis tanpa pemadanan peubah status dalam keluarga (X1), status perkawinan (X2), dan kategori pendidikan (X3) berpengaruh nyata terhadap status seseorang menganggur atau bekerja. Berdasarkan uji parsial, seluruh peubah boneka untuk ketiga peubah tersebut signifikan pada taraf nyata 5 persen. Selanjutnya untuk pemodelan dengan conditional logistic regression tabel tersebut menunjukkan bahwa ketiga peubah tersebut juga berpengaruh pada pada status seseorang menganggur atau bekerja. Namun, uji parsial menunjukan bahwa hanya peubah boneka bukan kepala rumah tangga (D1), peubah boneka status perkawinan kawin (D21), dan peubah boneka tingkat pendidikan Diploma dan di atasnya (D33) yang nyata pada taraf 5 persen.

Tabel 2: Dugaan Parameter Regresi Logistik tanpa Pemadanan (Unconditional Logistic Regression) dan dengan Pemadanan (Conditional Logistic Regression)

\begin{tabular}{|c|c|c|c|c|c|c|c|c|c|c|c|}
\hline \multirow[b]{2}{*}{ Peubah } & \multicolumn{5}{|c|}{ Unconditional Logistic Regression } & \multicolumn{6}{|c|}{ Conditional Logistic Regression } \\
\hline & Koef & $\begin{array}{c}\text { SE } \\
\text { Coef }\end{array}$ & $\begin{array}{c}\mathrm{P}- \\
\text { value }\end{array}$ & $\begin{array}{l}\text { Odds } \\
\text { Ratio }\end{array}$ & $95 \% \mathrm{Cl}$ & Koef & $\begin{array}{c}\text { SE } \\
\text { Coef }\end{array}$ & $\begin{array}{c}\text { P. } \\
\text { value }\end{array}$ & $\begin{array}{l}\text { Odds } \\
\text { Ratio }\end{array}$ & $95 \%$ & $\mathrm{Cl}$ \\
\hline Konstanta & -3.379 & 0.155 & 0.000 & 0.034 & $0.025 \quad 0.046$ & & & & & & \\
\hline \multicolumn{12}{|l|}{ Status dalam Keluarga (X1) } \\
\hline 2 Bukan Kepala Rumah Tangga & 1.035 & 0.107 & 0.000 & 2.815 & $2.285 \quad 3.470$ & 2.097 & 0.313 & 0.000 & 8.144 & 4.413 & 15.028 \\
\hline \multicolumn{12}{|l|}{ Status Perkawinan (X2) } \\
\hline 2 Kawin & -0.964 & 0.139 & 0.000 & 0.381 & 0.2910 .502 & -1.499 & 0.475 & 0.002 & 0.223 & 0.088 & 0.567 \\
\hline 3 Cerai & 1.286 & 0.145 & 0.000 & 3.617 & $2.725 \quad 4.817$ & -0.550 & 0.513 & 0.283 & 0.577 & 0.211 & 1.576 \\
\hline \multicolumn{12}{|l|}{ Kategori Pendidikan (X3) } \\
\hline 2 SMP dan sederajat & -1.199 & 0.160 & 0.000 & 0.302 & $0.218 \quad 0.409$ & 0.074 & 0.279 & 0.791 & 1.077 & 0.623 & 1.860 \\
\hline 3 SMA dan sederajat & -1.488 & 0.148 & 0.000 & 0.226 & $0.168 \quad 0.300$ & -0.054 & 0.256 & 0.833 & 0.947 & 0.573 & 1.566 \\
\hline 4 Diploma dan diatasnya & -2.122 & 0.287 & 0.000 & 0.120 & $0.065 \quad 0.202$ & -1.498 & 0.413 & 0.000 & 0.224 & 0.099 & 0.503 \\
\hline
\end{tabular}

Secara umum terjadi perubahan koefisien regresi baik tanda maupun nilainya dari pemodelan data sebelum pemadanan dengan regresi logistik tidak bersyarat dan pemodelan data sesudah pemadanan dengan regresi logistik bersyarat. Nilai rasio odds secara langsung juga terjadi perubahan. Seseorang yang bukan kepala rumah tangga akan memiliki resiko menganggur 2,815 kali dibandingkan seseorang yang berstatus kepala rumah tangga pada pemodelan regresi logistik tidak bersyarat dengan data sebelum pemadanan. Namun, pada pemodelan regresi logistik bersyarat dengan data pemadanan resiko menganggur pada seorang bukan kepala rumah tangga menjadi 8,144 kali dibanding seorang yang berstatus kepala rumah tangga. Hal ini terlihat bahwa efek dari confounder pada peubah ini adalah mengurangi hubungan yang sebenarnya dari status kepala rumah tangga terhadap status pengangguran. Hasil tersebut sejalan dengan penelitian Hartina (2009). Tingginya resiko seorang yang bukan kepala rumah tangga untuk menganggur dibandingkan kepala rumah tangga dikarenakan adanya tanggung jawab yang lebih besar seorang kepala rumah tangga dalam keluarga. 
Seseorang yang berstatus belum kawin akan memiliki resiko menganggur sebesar 2,625 kali dibanding seseorang dengan status kawin pada pemodelan regresi tidak bersyarat dengan data tanpa pemadanan. Hal ini sesuai dengan hasil penelitian dari Rochaningrum and Nihayah (2018) yang menyatakan bahwa status kawin cenderung mengurangi resiko untuk menganggur atau tidak bekerja jika dibandingkan yang belum kawin. Namun, hasil pada pemodelan bersyarat dengan data pemadanan, besarnya resiko menganggur untuk seorang yang belum kawin meningkat menjadi 4,484 kali dibanding seseorang yang kawin. Hal ini menunjukan efek adanya confounder adalah mengurangi besarnya hubungan yang sebenarnya.

Pada pemodelan regresi logistik tidak bersyarat dengan data tanpa pemadanan, seseorang yang memiliki pendidikan SD dan di bawahnya memiliki resiko menganggur sebesar 8,35 kali dibanding seseorang dengan pendidikan Diploma dan di atasnya. Sedangkan pada pemodelan regresi logistik bersyarat dengan pemadanan, besarnya resiko seseorang dengan pendidikan SD dan di bawahnya untuk menganggur menjadi 4,47 kali dibandingkan seseorang dengan pendidikan Diploma dan di atasnya. Berdasarkan hasil tersebut efek dari confounder adalah melebihkan besarnya hubungan yang sebenarnya. Hasil tersebut sesuai dengan teori human capital oleh Mankiw (2006) yang menyatakan bahwa seseorang dengan pendidikan formal lebih tinggi akan memperoleh kesempatan bekerja yang lebih tinggi dibandingkan dengan seseorang yang memiliki pendidikan rendah.

Peubah boneka lainnya (D22, D31, D32) tidak signifikan pada taraf nyata 5 persen pada pemodelan regresi logistik bersyarat dengan data pemadanan, namun signifikan pada pemodelan regresi logistik tidak bersyarat dengan data tanpa pemadanan. Pengaruh pada model regresi logistik tidak bersyarat dengan data sebelum dipadankan tersebut bukan murni pengaruh dari peubah bebas terhadap peubah respon, namun karena latar belakang responden (daerah tempat tinggal, jenis kelamin, dan usia) yang berbeda. Kesimpulan yang diambil jika didasarkan pada pemodelan tidak bersyarat dengan data sebelum pemadanan dapat tidak mencerminkan kondisi sebenarnya karena masih terpengaruh adanya peubah confounding. Hal ini menunjukan bahwa keberadaan peubah confounding akan menyesatkan kesimpulan yang diambil. Hasil pemodelan dengan menggunakan model regresi logistik bersyarat pada data yang dipadankan akan mengeliminasi efek confounder dan menghasilkan kesimpulan yang lebih valid.

\section{Simpulan dan Saran}

Hasil penelitian ini menunjukkan bahwa model regresi logistik bersyarat dengan data yang dipadankan memberikan hasil yang berbeda dibandingkan model regresi logistik tidak bersyarat pada data sebelum pemadanan. Hal ini disebabkan karena pengaruh peubah kovariat dan peubah confounding yang dapat mendistorsi hubungan antara peubah penjelas dan peubah respon yang sebenarnya. Pada pemodelan regresi logistik tidak bersyarat semua peubah bebas berpengaruh nyata terhadap status menganggur atau bekerja. Namun, pada pemodelan regresi logistik bersyarat dengan data setelah dipadankan, hanya peubah status dalam keluarga, status perkawinan (kawin), dan tingkat pendidikan (Diploma dan di atasnya) yang berpengaruh nyata terhadap status menganggur atau bekerja. Ini merupakan indikasi bahwa ragam penduga dari regresi logistik tidak bersyarat cenderung berbias ke bawah 
(underestimated). Seseorang dengan status bukan kepala rumah tangga memiliki resiko untuk menganggur yang lebih besar dibandingkan dengan orang yang berstatus sebagai kepala rumah tangga. Seseorang dengan pendidikan SD dan di bawahnya memiliki resiko untuk menganggur yang lebih besar dibandingkan dengan orang yang berpendidikan Diploma dan di atasnya. Seseorang dengan status kawin memiliki resiko untuk menganggur yang lebih besar dibandingkan dengan orang yang belum kawin.

\section{Daftar Pustaka}

Agresti, A. (2002). Categorical data analysis (2nd ed). New York: Wiley-Interscience.

[BPS]. (2017). Pedoman Pencacah Survei Angkatan Kerja Nasional. Jakarta: BPS.

[BPS]. (2018). Survei Angkatan Kerja Nasional. Jakarta: Badan Pusat Statistik.

Hartina, D. (2009). FAKTOR-FAKTOR YANG MEMPENGARUHI PENGANGGURAN TERSELUBUNG DI PERDESAAN JAWA TENGAH Analisis Data Sakernas 2007. Jurnal Kependudukan Indonesia, 4(1): 15-32. https://doi.org/10.14203/jki.v4i1.175

Hosmer, D. W., \& Lemeshow, S. (2000). Applied Logistic Regression (Second Edition). New York: Wiley-Interscience.

Kevin, A. (2019). Disebut Pemerintah Rendah, Pengangguran RI Tertinggi di ASEAN. In https://www.cnbcindonesia.com/. Retrieved from https://www.cnbcindonesia.com/news/20190317185220-4-61119/disebutpemerintah-rendah-pengangguran-ri-tertinggi-di-asean

Kuo, C.-L., Duan, Y., \& Grady, J. (2018). Unconditional or Conditional Logistic Regression Model for Age-Matched Case-Control Data? Frontiers in Public Health, 6. https://doi.org/10.3389/fpubh.2018.00057

Mankiw, N. G. W. (2006). PRINCIPLES OF ECONOMICS: PENGANTAR EKONOMI MIKRO, Edisi $3 . \quad 3$ Retrieved //digilib.unsri.ac.id/opac/index.php?p=show_detail\&id=69057\&keywords=

Pearce, N. (2016). Analysis of matched case-control studies. BMJ, 352: 1969. https://doi.org/10.1136/bmj.i969

Rochaningrum, E., \& Nihayah, D. M. (2018). Faktor yang Mempengaruhi Keputusan Tenaga Kerja Sarjana untuk Bekerja atau Tidak Bekerja. Economics Development Analysis Journal, 7(1): 60-67. https://doi.org/10.15294/edaj.v7i1.21931

Sukirno, S., \& Sukirno, S. (2010). Makroekonomi: teori pengantar / Sadono Sukirno. 1. EKONOMI MAKRO,Makroekonomi: Teori Pengantar / Sadono Sukirno, 2010(2010): 1-99. https://doi.org/2010 